\title{
Optimization of the tetrazolium test in three species of orchids of the Andean forest
}

\author{
Seir Antonio Salazar Mercado ${ }^{1}$, Jesús David Quintero Caleño ${ }^{2 *}$, Jhan Piero Rojas Suárez ${ }^{3}$ \\ ${ }^{1}$ Department of Biology, Universidad Francisco de Paula Santander, Avenida Gran, Colombia \#12E-96B Colsag, San José \\ de Cúcuta, Norte de Santander, Postal Code:540003, Colombia \\ ${ }^{2}$ Department of Agricultural Sciences, Universidad Francisco de Paula Santander, Avenida Gran Colombia \#12E-96B \\ Colsag, San José de Cúcuta, Norte de Santander, Postal Code:540003, Colombia \\ ${ }^{3}$ Department of Civil Constructions, Roads, Transportation, Hydraulics and Fluids, Universidad Francisco de Paula \\ Santander, Avenida Gran Colombia \#12E-96B Colsag, San José de Cúcuta, Norte de Santander, Postal Code:540003, \\ Colombia
}

*Corresponding authors: davidquintero93@outlook.com, jesusdavidqc@ufps.edu.co

Abstract

In order to improve the cultivation and conservation of orchid species, it is important to assess the physiological quality of orchid seeds. One of the most traditional tests for analysing seed quality is the tetrazolium test, whose effectiveness is known to improve with pre-treatment of the seeds. As a result, this study compared various pre-treatments to determine how efficient they were at optimising the tetrazolium test in seeds belonging to Cyrtochilum aemulun, Elleanthus aurantiacus and Lephantes sp. The experiment was based on five different pre-treatment solutions, after which the seeds were exposed to tetrazolium at two different concentrations and for three different exposure times. First, the seeds were soaked for ten minutes in one of five pre-treatment solutions: chlorine $0.5 \%$, chlorine $1 \%$, deionised water, sucrose solution $10 \%(\mathrm{w} / \mathrm{v})$ or a control in which no pre-treatment was applied. After pre-treatment, the seeds were soaked in the dark in a tetrazolium solution, either at $0.25 \%$ concentration or at $1.0 \%$ concentration, and for either 6, 24 or 48 hours. The control seeds exposed to no pre-treatment showed an increase in the viability of Lephantes sp. at significant difference from the pre-treated seeds. Similarly, pre-treatment with $10 \%$ sucrose produced an increase in the tetrazolium test's effectiveness in E.aurantiacus seeds, with significant differences from the control in most treatments. Therefore, the use of sucrose as a pre-treatment is recommended, in addition to increasing the concentration and exposure time of the seeds.

Keywords: Cyrtochilum, Chlorine, Efficiency, Orchids, Sucrose, Viability.

Introduction

The Orquidaceae family is one of most diverse in terms of species (Almasi et al., 2013), but also has one of the highest risks of extinction in the plant kingdom (Zhang et al., 2018; Jeyanthi et al., 2013). It comprises one of the most diversified taxa among the phanerogams (APG III, 2009), belonging to the order Asparagales, and is considered the second largest plant family (Apolinário, 2017). It is known for its long-lived and beautiful flowers which vary in shape, colour and scent (Jeyanthi et al., 2011; Van der Niet, 2018), having between 25,000 to 30,000 species distributed among 880 genera (Salazar and Gélvez, 2015; Gnasekaran et al., 2012), as well as approximately six thousand hybrids (Menchaca, 2011). It has developed specialized adaptations, such as bulky stems that form pseudobulbs and canopy roots, allowing for the colonization of different types of environments and its establishment in a wide variety of habitats, where they can be epiphytes, terrestrial, rupicolous (Vij and Phatak, 2012) and infrequently saprophytic. They are absent only from polar and desert regions, but they are particularly abundant in the humid tropics worldwide (Zhang et al., 2018). They are distributed throughout tropical and temperate climates, where terrestrial orchids account for about one third of all known species.

In Colombia, orchids are one of the most abundant and diverse groups of vascular epiphytes (Betancur et al., 2015). However, few studies have been conducted in Colombia on orchid populations, and many of the factors that determine reproductive success in different ecosystems remain unknown (González et al., 2017). According to the most recent data provided by the Ministry of Environment and Sustainable Development and the National University of 
Colombia (2015), 4270 species and 274 genera have been registered in Colombia, with 105 species and 37 genera in the department of North Santander alone (Salazar and Gélvez, 2015). Due to their floral characteristics, orchids are attractive for trading, being considered the group of plants with the greatest potential for commercialisation (Roberts and Dixon, 2008; Nambiar et al., 2012).

Despite orchids featuring one of the most cited examples of nuclear embryony among the angiosperms, little is known about their reproductive success (Campacci et al., 2017) and the available research has focused on the symbiotic relationship with mycorrhizal fungi (Vudala et al., 2019). Similarly, few studies have carefully examined the reproductive process of orchid species (Huang et al., 2009). Often dubbed "dust" seeds (due to their starch-like appearance), orchid seeds are the smallest in the plant kingdom (Dalzotto and Lallana, 2015). Oscillating between 1.0-2.0 mm long and 0.5-1.0 mm wide and lacking an endosperm, they feature only one testa and one immature embryo (Billard et al., 2014). The number of seeds per capsule is variable, being generally less than 100,000 (Silva et al., 2015) although there are reports of more than one million seeds per capsule (Lallana et al., 2010).

Seeds germinate at a rate of only 10 to 15 per million, with one or two becoming adult plants after two or three years (Ordoñez et al., 2016). According to Carvalho et al. (2013), crop yield depends predominantly on seed quality, since seeds are the primary means of propagation (Doria, 2010; Waraich et al., 2013) both in crop production and storage. Therefore, information both on seed viability and on the germination rate (Al-Turki and Baskin, 2017) play a significant role (Arenas et al., 2015). As orchids are prone to seed dormancy (Johansen and Rasmussen, 1992), it is important to assess seed batches in order to know their quality before sowing. The use of rapid tests to determine seed quality is an indispensable tool; therefore, such tests deserve the attention of professionals, producers and researchers (Deminicis et al., 2009; Salazar et al., 2020). The viability of orchids is usually tested by the tetrazolium test and in vitro germination (Vudala et al., 2019). The tetrazolium test is based on the enzyme activity of malate dehydrogenase in the mitochondria, which reacts with tetrazolium to form a red, stable and insoluble substance called formazan (Salazar and Botello, 2018). This reaction thereby makes it possible to distinguish the living parts, coloured in red, from those which are dead, which maintain their original colour (Abbade and Takaki, 2014). To perform the tetrazolium test, procedures are needed to improve its effectiveness. These are known as pre-treatments or conditioning tests, which help the tetrazolium solution to penetrate into the tissues (Santos et al., 2017). Numerous studies have aimed to standardize the procedures developed for the Orquidacea family, such as in Cattleya labiata and C. tigrina (Hosomi et al., 2017), Aerides maculosum (Deepti et al., 2013), Aerides ringens (Deepti et al., 2015), Dactylorhiza Fuchsii and Vanda curvifolia (Custódio et al., 2016), Cattleya mendelli (Salazar-Mercado, 2012), Thelymitra pauciflora and Prasophyllum pruinosum (Dowling and Jusaitis, 2012), among others. In general terms, such pre-treatments seek to improve the efficacy of the test, reducing interpretation errors by analysts (Zucareli et al., 2001). Taking the above into account, this research aims to optimise the application of the tetrazolium test on seeds of the Orquidaceae family through the development of a protocol that can achieve a practical methodology. Consequently, the following study evaluates the effect of five pre-treatments on the efficacy of the tetrazolium test as used to determine the viability of seeds belonging to Cyrtochilum aemulun, Elleanthus aurantiacus and Lephantes sp.

Results

\section{Cyrtochilum aemulun viability}

Regarding the results in seeds belonging to Cyrtochilum aemulun, important figures were obtained in the control (without pre-treatment), which showed a mean viability of $77.7 \%$ (Table 2; Figures $2 \mathrm{~A}$ and B), with $94.6 \%$ viability observed in the T11 solution $10.25 \%$ tetrazolium concentration exposed for 48 hours) and $44 \%$ viability observed in T16 (1.0\% for 6 hours). T16 showed statistically significant differences with respect to the other the pretreatments at the same concentration and exposure time (1.0\% and 6 hours). On the other hand, pre-treatment with chlorine $0.5 \%$ resulted in a mean viability of $89.9 \%$, with $97.3 \%$ viability observed for T22 (1.0\% for 24 hours) and T12 ( $0.25 \%$ for 48 hours) treatments, which did not show statistically significant differences from the other pretreatments (T11, T13, T14 and T15), and a minimum value of $70.6 \%$ viability in $\mathrm{T} 2(0.25 \%$ for 6 hours). Similarly, the use of $1 \%$ Chlorine resulted in a mean viability of $75.2 \%$, a maximum viability of $88 \%$ for the T13 treatment $(0.25 \%$ for 48 hours) and a minimum viability of $48 \%$ for the T28 treatment (1.0\% for 48 hours). T28 showed statistically significant differences compared to the other pretreatments at the same tetrazolium concentration and exposure time (T26, T27, T29 and T30). By contrast, it was observed that the use of deionized water as a pretreatment provided a $98.6 \%$ viability in the treatments T24 (1.0\% for $24 \mathrm{~h}$ ) and T29 (1.0\% for 48 hours), with a minimum of $72 \%$ viability in T19 (1.0\% for 6 h). Finally, it should be noted that the use of sucrose provided the highest results for the tetrazolium test in $C$. aemulun seeds (Table 2 ), with an mean viability of $95.4 \%$, as well as a maximum viability of $98.6 \%$ in the T15 treatments ( $0.25 \%$ for 48 hours) and T30 (1.0\% for 48 fours) and a minimum viability of $91.3 \%$ in T5 (0.25\% for 6 hours).

\section{Elleanthus aurantiacus viability}

The interaction between using pre-treatment and applying the tetrazolium test to seeds belong to Elleanthus aurantiacus showed clearly contrasting results in the obtained values (Table 3; Figure $2 \mathrm{C}$ and D ). A mean viability of $5.95 \%$ was observed in the control pre-treatment, this being the lowest among the pre-treatments, with a maximum viability value of $13.3 \%$ in the T21 treatment (1.0\% for 24 hours) and $1.3 \%$ viability in the T6 treatment (0.25\% for 24 hours), which showed statistically significant differences from the other treatments at the same concentration and exposure time to tetrazolium (T7, T8, T9 
and T10). Next, pre-treatment with chlorine $0.5 \%$ showed a viability of $29.3 \%$ for the T7 treatment ( $0.25 \%$ for 24 hours), as well as $1.3 \%$ viability for T12 and T27 ( $1.0 \%$ for 48 hours). On the other hand, pre-treatment with chlorine $1 \%$ resulted in $14.6 \%$ viability for the T8 treatment $(0.25 \%$ for 24 hours) and $1.3 \%$ viability for T13 and T2, with a total mean viability of $7 \%$, which is data statistically homogeneous with the control pre-treatment and pretreatment with chlorine $0.5 \%$ (Table 3 ). On the contrary, it is observed that the use of deionized water resulted in the highest viability, with a mean of $22.4 \%$ and $34.6 \%$ in the T9 treatment $(0.25 \%$ for 24 hours), and a minimum value of $10.6 \%$ in $\mathrm{T} 29$, which did not show significant differences with respect to the treatments T26, T27, T28 and T30. On the other hand, the use of sucrose $(10 \% \mathrm{w} / \mathrm{v})$ produced a minimum viability of $8 \%$ for T30 $(1.0 \%-48 \mathrm{~h})$ without significant differences compared to the other treatments at the same concentration and exposure time (T26, T27, T28 and T29), while obtaining $40 \%$ viability in the T10 treatment (0.25\% for $24 \mathrm{~h})$.

\section{Lephantes sp viability test}

The study conducted on Lephantes sp (Figures $2 \mathrm{E}$ and $\mathrm{F}$ ) yielded intermediate results compared to the other species studied (C. aemulun and E. aurantiacus). In this case, the control pre-treatment showed a maximum viability of $96 \%$ in the T11 treatment ( $0.25 \%$ for 48 hours), an important figure as it presented statistically significant differences from all other treatments at the same concentration and exposure time except for T15 (sucrose $10 \% \mathrm{w} / \mathrm{v}$ ). The control pre-treatment showed a minimum viability of $49.3 \%$ in T16 (1.0\% for 6 hours), with T16 showing significant differences from the other treatments (T17, T18, T19 and T20). Next, pre-treatment with chlorine $0.5 \%$ showed its highest viability at $18.6 \%$ with $\mathrm{T} 2,0 \%$ with $\mathrm{T} 22$ and $1.3 \%$ with T7, T12 and T17 (1.0\% for 6 hours). T7, T12 and T17 did not show significant differences among themselves (Table 4). Similarly, pre-treatment with $1 \%$ chlorine resulted in $86.6 \%$ viability with treatment T18 (1.0\% for 6 hours) and $1.3 \%$ viability for T8, T23 (1.0\% for 24 hours) and T28, resulting on average in higher viability than the $0.5 \%$ chlorine pre-treatment $0.5 \%$, but lower viability than with pre-treatments (the control, deionized water and sucrose.). On the contrary, it is observed that the use of deionized water as a pre-treatment gave rise to a mean viability of $70.1 \%$, with $92 \%$ viability in the case of T24 treatment. Likewise, the use of sucrose $(10 \% \mathrm{w} / \mathrm{v})$ resulted in $96 \%$ viability with T30 treatment, contrasting with $2.6 \%$ with T20 (1.0\% for 6 hours) and $4 \%$ with T5. T20 and T5 did not show statistically significant differences between them.

\section{Discussion}

The results obtained in seeds belonging to $C$. aemulun show that pre-treatment with $1 \%$ chlorine leads to lower values of variability than the other pre-treatments (Table 2), decreasing on average the efficacy of the test compared to chlorine $0.5 \%$ (by $89.9 \%$ ), deionized water (by $87.6 \%$ ) and sucrose by $95.4 \%$ ), but maintaining parity with the mean obtained by the pre-treatment control (Table 2). This data is consistent with results seen in freshly collected seeds of Paphiopedilum SCBG Red Jewel, where the use of $1 \%$ chlorine pre-treatment caused a substantial decrease in staining with $1 \%$ tetrazolium solution and 24 hours of exposure (Fu et al., 2016). Likewise, this supports the results in Oncidium bifolium seeds obtained by Dalzotto et al. (2013), where the use of $\mathrm{NaClO}$ negatively influenced viability, increasing the proportion of non-viable seeds, likely due to the fact that, despite $\mathrm{NaClO}$ being an efficient scarifier in orchid seeds (Bae et al., 2014), the concentration at $1 \%$ can damage the embryo and thereby reduce viability. It is known that sodium hypochlorite can decrease seed viability by exacerbating prior mechanical damage (Strobel et al., 2016). According to Salazar et al. (2019); Salazar and Maldonado (2020), Sodium hypochlorite causes a cytotoxic effect by generating cellular anomalies. It is also observed that the use of deionized water as a pre-treatment resulted in a mean viability of $87.6 \%$, making it the most feasible pre-treatment in budgetary terms as it did not show significant differences from pre-treatment with sucrose $(10 \% \mathrm{w} / \mathrm{v})$, nor from pretreatment with chlorine $0.5 \%$, allowing for reduced costs when applying the test (Carvalho et al., 2017).

Regarding the control pre-treatment in Elleanthus aurantiacus seeds, we observed similar results to those obtained by Hosomi et al. (2017) in seeds belonging to Cattleya labiata and Cattleya tigrine, where viability was found at its the lowest values with the control and where, as in our study, there were no statistically significant differences from the use of chlorine, possibly because the presence of impervious structures in the seed coat can prevent the entrance of tetrazolium solution into the embryo (Custódio et al., 2016). The results obtained with deionized water were similar to those obtained in Daucus carota seeds pre-treated with deionized water by Lima et al. (2018), where pre-treatment with deionised water yielded the highest viability, regardless of the tetrazolium salt's concentration $(0.5 \%$ and $1 \%)$ and exposure time (6 hours and 24 hours, in Table 3). This reaffirms that hydration triggers the activation of enzymatic metabolism, which facilitates the absorption of tetrazolium (Carvalho et al., 2017) and ensures the efficacy of the test. It is worth noting that, in this study, pre-treatment with sucrose $(10 \%$ $\mathrm{w} / \mathrm{v}$ ) also improved the tetrazolium test by a mean of $20.1 \%$ without significant differences from pre-treatment with deionized water. Furthermore, sucrose $(10 \% \mathrm{w} / \mathrm{v})$ in this study resulted in the highest viability in the experiments conducted on this species ( $40 \%$ for the T10 treatment), which are results in line with those obtained by Hosomi et al. (2017) in C. labiata and C. tigrina seeds pre-treated with $10 \%(\mathrm{w} / \mathrm{v})$ sucrose solution, where this solution yielded the highest efficiency in the $1 \%$ tetrazolium test over 24 hours of exposure.

In the species Lepanthes $\mathrm{sp}$, the control pre-treatment was the most efficient in the viability test with a mean of $77.06 \%$ (Table 4), which is a noteworthy result as it allows for savings in compounds such as $\mathrm{NaClO}$ and sucrose when conducting the tetrazolium test on this species, which will enable an increase in studies while maintaining the same input costs. Pre-treatment with chlorine $0.5 \%$ was the least efficient with a mean viability of $4.1 \%$, contrasting with the 
Table 1. Formation of treatments used in each of the three species of orchids.

\begin{tabular}{lllllll}
\hline Different concentrations and exposure times with tetrazolium applied to each of the species. \\
\hline Pre-treatments & $0.25 \%-6 \mathrm{~h}$ & $0.25 \%-24 \mathrm{~h}$ & $0.25 \%-48 \mathrm{~h}$ & $1.0 \%-6 \mathrm{~h}$ & $1.0 \%-24 \mathrm{~h}$ & $1.0 \%-48 \mathrm{~h}$ \\
\hline Control & T1 & $\mathrm{T} 6$ & $\mathrm{~T} 11$ & $\mathrm{~T} 16$ & $\mathrm{~T} 21$ & $\mathrm{~T} 26$ \\
Chlorine $0.5 \%$ & $\mathrm{~T} 2$ & $\mathrm{~T} 7$ & $\mathrm{~T} 12$ & $\mathrm{~T} 17$ & $\mathrm{~T} 22$ & $\mathrm{~T} 27$ \\
Chlorine 1\% & T3 & $\mathrm{T} 8$ & $\mathrm{~T} 13$ & $\mathrm{~T} 18$ & $\mathrm{~T} 23$ & $\mathrm{~T} 28$ \\
H2Od & $\mathrm{T} 4$ & $\mathrm{~T} 2$ & $\mathrm{~T} 14$ & $\mathrm{~T} 19$ & $\mathrm{~T} 24$ & $\mathrm{~T} 29$ \\
Sucrose 10\% & T5 & $\mathrm{T} 10$ & $\mathrm{~T} 15$ & $\mathrm{~T} 20$ & $\mathrm{~T} 25$ & $\mathrm{~T} 30$ \\
\hline
\end{tabular}

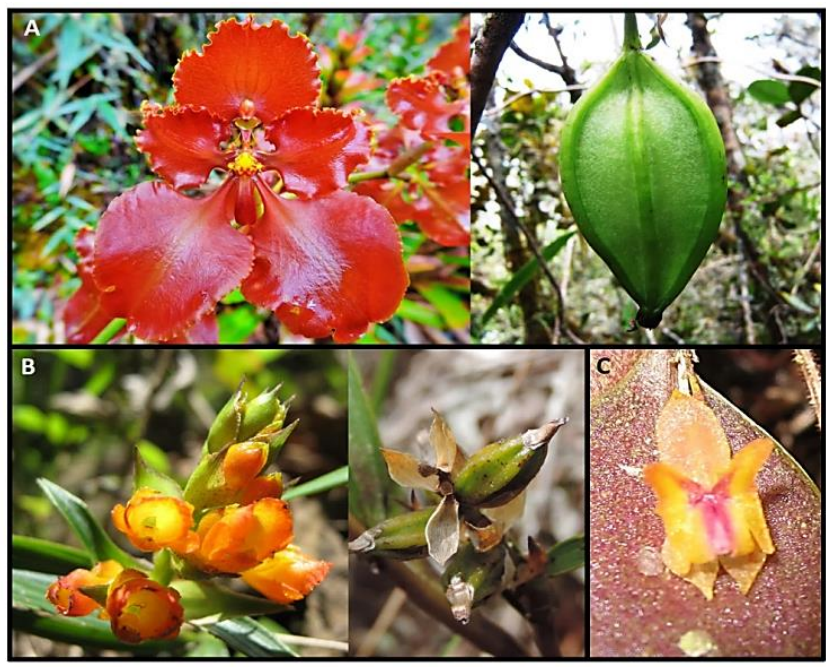

Fig 1. Flowers and capsules of the orchids studied species. (A) flower and capsule of C. aemulun. (B) flower and capsule of $E$. aurantiacus. (C) Lephantes sp. Flower.

Table 2. Cyrtochilum aemulun seeds viability submitted to five pretreatments and evaluated by the tetrazolium test at different concentrations and exposure times.

\begin{tabular}{llccllll}
\hline Pre-treatments & $0.25 \%-6 \mathrm{~h}$ & $0.25 \%-24 \mathrm{~h}$ & $0.25 \%-48 \mathrm{~h}$ & $1.0 \%-6 \mathrm{~h}$ & $1.0 \%-24 \mathrm{~h}$ & $1.0 \%-48 \mathrm{~h}$ & Mean \\
\hline Control & $66.6^{\mathrm{a}}$ & $90.6^{\mathrm{a}}$ & $94.6^{\mathrm{a}}$ & $44^{\mathrm{a}}$ & $80^{\mathrm{a}}$ & $90.6^{\mathrm{a}}$ & 77.7 \\
Chlorine 0.5\% & $70.6^{\mathrm{a}}$ & $96^{\mathrm{a}}$ & $97.3^{\mathrm{a}}$ & $86.6^{\mathrm{b}}$ & $97.3^{\mathrm{b}}$ & $92^{\mathrm{a}}$ & 89.9 \\
Chlorine 1\% & $82^{\mathrm{a}, \mathrm{b}}$ & $77.3^{\mathrm{a}}$ & $88^{\mathrm{a}}$ & $86.6^{\mathrm{b}}$ & $69.3^{\mathrm{a}}$ & $48^{\mathrm{b}}$ & 75.2 \\
H2Od & $77^{\mathrm{a}, \mathrm{b}}$ & $82.6^{\mathrm{a}}$ & $97.3^{\mathrm{a}}$ & $72^{\mathrm{a}, \mathrm{b}}$ & $98.6^{\mathrm{b}}$ & $98.6^{\mathrm{a}}$ & 87.6 \\
Sucrose 10\% & $91.3^{\mathrm{b}}$ & $93.3^{\mathrm{a}}$ & $98.6^{\mathrm{a}}$ & $94.6^{\mathrm{b}}$ & $96^{\mathrm{b}}$ & $98.6^{\mathrm{a}}$ & 95.4 \\
\hline
\end{tabular}

The values of the means with different letters of each column indicate statistically significant differences, according to the Tukey HSD test (P $\leq 0.05)$.

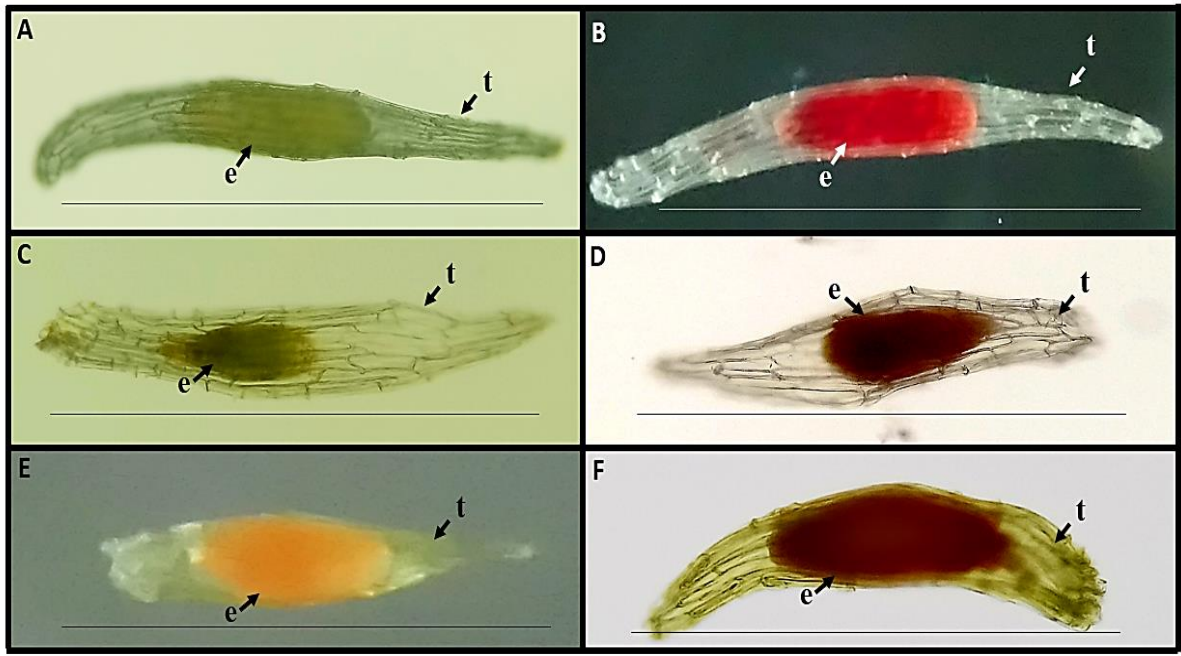

Fig 2. Viability test using Tetrazolium. (A) C. aemulun non-viable seed. (B) C. aemulun viable seed. (C) E. aurantiacus non-viable seed. (D) E. aurantiacus viable seed. (E) Lephantes sp. non-viable seed. (F) Lephantes sp. viable seed. Bar scale $1 \mathrm{~mm}$. t: seed coat; e: embryo. 
Table 3. E. aurantiacus seeds viability.

\begin{tabular}{|c|c|c|c|c|c|c|c|}
\hline Pre-treatments & $0.25 \%-6 h$ & $0.25 \%-24 \mathrm{~h}$ & $0.25 \%-48 \mathrm{~h}$ & $1.0 \%-6 \mathrm{~h}$ & $1.0 \%-24 \mathrm{~h}$ & $1.0 \%-48 \mathrm{~h}$ & Mean \\
\hline Control & $6.6^{\mathrm{a}}$ & $1.3^{\mathrm{a}}$ & $1.3^{\mathrm{a}}$ & 2.6a & $13.3^{\mathrm{a}^{\mathrm{b}}}$ & $10.6^{a}$ & 5.95 \\
\hline Chlorine $0.5 \%$ & $13.3^{\mathrm{a}}$ & $29.3^{c}$ & $1.3^{\mathrm{a}}$ & $14.6 \underline{a}^{\mathrm{a}, \mathrm{b}}$ & $13.3^{a^{, b}}$ & $1.3^{\mathrm{a}}$ & 12.1 \\
\hline Chlorine $1 \%$ & $4^{a}$ & $14.6^{\mathrm{b}}$ & $1.3^{\mathrm{a}}$ & $10.6^{a^{, b}}$ & $10.6^{a}$ & $1.3^{\mathrm{a}}$ & 7 \\
\hline $\mathrm{H} 2 \mathrm{Od}$ & $21.3^{\mathrm{a}}$ & $34.6^{c}$ & $12^{\mathrm{b}}$ & $28.0^{c}$ & $28^{\mathrm{b}}$ & $10.6^{a}$ & 22.4 \\
\hline Sucrose $10 \%$ & $21.3^{a}$ & $40^{c}$ & $10.6^{\mathrm{b}}$ & $21.3^{\mathrm{b}, \mathrm{c}}$ & $19.6 a^{, b}$ & $8^{a}$ & 20.1 \\
\hline
\end{tabular}

The values of the means with different letters of each column indicate statistically significant differences, according to the Tukey HSD test (P $\leq 0.05$ ).

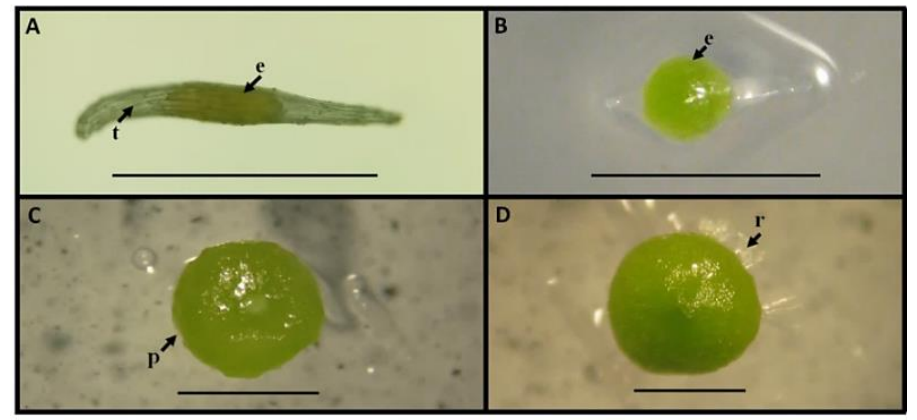

Fig 3. Asymmetric germination of $C$. aemulun seeds in the MS culture medium. (A) Not germinated seed. (B) Expanded embryo. (C) Rupture of the head and formation of protocorms (D) Production of rhizoids. Bar scale = $1 \mathrm{~mm}$. $\mathbf{t}$ : seed coat; e: embryo; $\mathbf{p}$ : protocorm; $\mathbf{r}$ : rhizoid.

Table 4. Lephantes $s p$ seeds viability.

\begin{tabular}{|c|c|c|c|c|c|c|c|}
\hline Pre-treatments & $0.25 \%-6 h$ & $0.25 \%-24 \mathrm{~h}$ & $0.25 \%-48 h$ & $1.0 \%-6 h$ & $1.0 \%-24 \mathrm{~h}$ & $1.0 \%-48 \mathrm{~h}$ & Mean \\
\hline Control & $78.62^{a}$ & 90.6a & $96^{\mathrm{a}}$ & $49.3^{a}$ & $62.6 a$ & $85.3 a$ & 77.06 \\
\hline Chlorine $0.5 \%$ & $18.6^{b, c}$ & $1.3^{\mathrm{b}}$ & $1.3^{\mathrm{b}}$ & $1.3 b$ & $\mathrm{Ob}$ & $2.6 b$ & 4.1 \\
\hline Chlorine 1\% & $26.6^{c}$ & $1.3^{\mathrm{b}}$ & $2.6^{b}$ & $86.6 c$ & $1.3 b$ & $1.3 b$ & 19.9 \\
\hline $\mathrm{H} 2 \mathrm{Od}$ & $73.3^{\mathrm{a}}$ & $73.3^{a}$ & $86.6^{c}$ & $6.6 b$ & $92 c$ & $89.3 a$ & 70.1 \\
\hline Sucrose $10 \%$ & $4^{b}$ & $84 \underline{a}$ & $90.6^{a^{, c}}$ & $2.6 \mathrm{~b}$ & $94.6 c$ & $96 c$ & 61.9 \\
\hline
\end{tabular}

results of Fu et al. (2016) in Paphiopedilum SCBG Red Jewel seeds, where the highest staining was obtained by pretreatment with $0.5 \%$ chlorine for 60 minutes. Our results with chlorine $0.5 \%$ also contradict those obtained by Custódio et al. (2016), in Dactylorhiza fuchsii seeds, where $0.5 \% \mathrm{NaOCl}$ over a time of 2.5 minutes led to a close correlation between the viability and germination of the seeds.

Ten days after planting the seeds in vitro, a change in the seeds' colour was observed (Figure 3. B), followed by the breaking of the seed coat, which indicates the absorption of water and nutrients to generate new cells (Figure 3.C), which leads to the formation of a protocorm (Sulong et al., 2016) and later to the formation of rhizoids (Figure 3.D). In the germination test in vitro for C. aemulun, a total of $95 \%$ was obtained, which correlates with the mean viability obtained upon exposing the seeds to sucrose $(10 \% \mathrm{w} / \mathrm{v})$. Scarifying with $\mathrm{NaOCl} 0.5 \%$ also provides important results, such as $96 \%$ viability in $\mathrm{T} 7$ and $97.3 \%$ viability in $\mathrm{T} 12$ and T22 (Table 2), which is statistically homogeneous with the percentage of real germination, which demonstrates that regardless of the concentration and time of exposure to tetrazolium, the use of sucrose at $10 \%(\mathrm{w} / \mathrm{v})$ and $\mathrm{NaOCl}$ at $0.5 \%$ is an efficient alternative for optimising the tetrazolium test in C. aemulun seeds. Furthermore, it demonstrates that it is not necessary to use a higher concentration of $\mathrm{NaOCl}$. In the case of E. aurantiacus, $94 \%$ in vitro germination was observed. In this species in particular, all viability values were well below the real germination rate, which showed no correlation with any of the results for viability from the tetrazolium test. Although pre-treatment with deionized water showed $22.4 \%$ viability, this was much lower than the $73.2 \%$ viability obtained by Salazar and Gélvez (2015) in E. aurantiacus seeds, using 1\% tetrazolium over 24 hours of exposure. In general terms, the use of pre-treatments did not guarantee an improvement in the tetrazolium test, but in fact decreased the effectiveness of the test, irrespective of concentration and exposure time. Therefore, it is necessary to assess the possible reasons why $E$. aurantiacus seeds respond negatively to the tetrazolium test, which may be related to the structure of the seed coat. According to Custídio et al. (2016), the presence of certain structures in the seed coat of some orchids can block the entry of substances into the embryo, which is why we recommend more in-depth studies be carried out to investigate the effect of the $E$. aurantiacus seed coat on the tetrazolium test. Lephantes $s p$. showed the lowest germination percentage of all the species in this study, which at $29 \%$ viability only correlated with the $26.6 \%$ viability obtained from T3 $(1 \% \mathrm{NaOCl}$, followed by $0.25 \%$ tetrazolium for 6 hours). T3 was, in turn, statistically homogenous with T2 $(0.5 \% \mathrm{NaOCl})$ with $18.6 \%$ viability. In this chain of ideas, it is important to highlight that hydrophobic compounds in the seed coast, such as lignin, are degraded by chlorine, which causes the seed coat to become more hydrophilic (Barserg et al., 2013). Although 
the germination percentage and the value of T2 are similar, the use of $0.5 \%$ chlorine resulted in a mean viability of $4.1 \%$ (Table 4), a figure which is not consistent with in vitro germination. The use of $1 \%$ chlorine as a pre-treatment, however, presented the closest approximation to real germination, differing by only $9 \%$, which confirms that using $\mathrm{NaOCl}$ can have a positive influence on the tetrazolium test (Bae et al., 2013). Finally, the discrepancy between viability and germination in the species studied may be due to differences in the characteristics of the seed cover, having repercussions on the effectiveness of dormancy tests (Lallana et al., 2018) and producing differences between the tetrazolium test and the germination test.

\section{Materials and methods}

\section{Plant material}

The experiment was conducted in the biology laboratory at the Francisco de Paula Santander University, using mature capsules of Cyrtochilum aemulun (N07'34'427'W072 64'176", 2882 masl), Elleanthus aurantiacus (N07'34'979"-W072 64'301"; 2651 masl) and Lephantes sp (N07 $34^{\prime} 78^{\prime \prime}-\mathrm{W} 072^{\circ} 64^{\prime} 81^{\prime \prime} ; 2750$ masl), obtained by natural pollination and collected from the village of El Escorial, in the municipality of Pamplona, Colombia, with an annual average temperature of $14.4^{\circ} \mathrm{C}$ and a total annual rainfall of $921 \mathrm{~mm}$ (IDEAM, 2018). Thereafter, the capsules were placed in kraft paper envelopes and kept at room temperature until dehiscence (approximately 24 hours later). After dehiscence, the seeds were washed with distilled water for the application of the pre-treatments (Table 1). To apply the pre-treatments, the syringe method described by Salazar et al. (2013) was used. For each pretreatment, a small portion of seeds was placed in a sterile 5 $\mathrm{ml}$ syringe with a cloth filter and soaked for 10 minutes in the respective pre-treatment (Table 1). Subsequently, three washes with deionized water were carried out and the tetrazolium test was applied.

\section{Tetrazolium tests}

Immediately after applying the pre-treatments and washing, the seeds were soaked in the tetrazolium solution in total darkness for the time corresponding to each treatment $(6,24$ and 48 hours). After this period, the tetrazolium solutions were removed and the seeds were washed three times with distilled water. Next, they were examined in the stereoscope microscope (Leica EZ4). The assessment of the seeds' viability was based on counting of the number of seeds that showed red coloration (viable), due to the reduction of tetrazolium by the cellular respiration (Salazar and Vega, 2017; Salazar and Botello, 2018). A lack of red coloration and/or or pale pink colours would indicate the death of the embryo or little viability. To quantify the viability percentage, the number of viable seeds in each of the repetitions and treatments was determined.

\section{Germination test}

With few exceptions, germinating orchid seeds in vitro has become increasingly popular both to propagate them and assess their viability (Mahmood et al., 2011; Baque et al., 2011). In this study, we used the basal medium MS, with the concentrations of macro and micronutrients at $100 \%$ (Murashige and Skoog, 1962), with $30 \mathrm{~g} / \mathrm{L}$ of sucrose, $8 \mathrm{~g} / \mathrm{L}$ of agar, and $1 \mathrm{~g} / \mathrm{L}$ of activated carbon. The $\mathrm{pH}$ was adjusted to 6.0 using $\mathrm{NaOH}$. Subsequently, the media were sterilized at 15 pounds of pressure (Psi) at $121^{\circ} \mathrm{C}$ for 20 minutes. 100 seeds (ten replicates) were cultivated under aseptic conditions, in petri dishes containing $20 \mathrm{~mL}$ of MS medium. The seeds were incubated under controlled environmental conditions of $20 \pm 2^{\circ} \mathrm{C}$, with a photoperiod of 16 hours' light and 8 hours' dark, with a light intensity of $28 \mu \mathrm{mol} \mathrm{m}-2 \mathrm{~s}-1$ given by fluorescent light and $65 \%$ relative humidity, for 60 days. The percentage of germination was obtained by observing 100 seeds per treatment with the help of a stereoscope microscope (Leica EZ4). This count directly showed the percentage of germination for each treatment. The seeds that had expanded embryos and a rupture of the testa according to Salazar et al. (2013) were considered germinated.

\section{Statistical analysis}

In the tetrazolium test, the data were randomly distributed, with 30 treatments for each studied species and ten replicates of one hundred experimental units per treatment. Viability and germination in the orchid seeds were expressed as a percentage. The data were analysed using the ANOVA analysis of variance. Then, the mean averages were compared using the multiple range test of HSD (Honest Significant Difference) from Tukey (Tukey, 1994), to determine the means with significant differences at a level of $P<0.05$. Statistical Centurion ${ }^{\circledR}$ software version 17 was used in the statistical analysis. KyploT 2.0 software was used to prepare the graphs as well.

\section{Conclusions}

It was determined that pre-treatment with $10 \%$ sucrose $(\mathrm{w} / \mathrm{v})$ improves the effectiveness of the tetrazolium test in Cyrtochilum aemulun seeds, demonstrating a better correlation with real germination (in vitro). In the case of Lephantes sp., it is observed that scarification with $10 \%$ $\mathrm{NaClO}$ presents the highest viability. However, there is no evidence that it increases the effectiveness of the test. On the other hand, it is recommended that new pre-treatment models be proposed for Elleanthus aurantiacus as the test's effectiveness was reduced in all cases.

\section{Acknowledgements}

To Universidad Francisco de Paula Santander (CúcutaColombia) for their valuable collaboration and project financing (FINU-UFPS: 037-2019).

References 
Abbade LC, Takaki M (2014) Teste de tetrazólio para avaliação da qualidade de sementes de Tabebuia roseoalba (Ridl.) Sandwith-Bignoniaceae, submetidas ao armazenamento. Revista Árvore. 38(2): 233-240.

Almasi P, Mohamed M, Ahmad S, Kadir J, Hassan F (2013) Postharvest responses of six cut Mokara spp. hybrids to exogenous ethylene. Aust J Crop Sci. 7: 894-899.

Al-Turki T, Baskin C (2017) Determination of seed viability of eight wild Sandi Arabian species by germination and X-ray tests. Saudi J Biol Sci. 24(4): 822-829.

Angiosperm Phylogeny Group III (2009) An update of the Angiosperm Phylogeny Group classification for the orders and families of flowering plants: APG III. Botanical J Linnean Society. 161. 105-121.

Apolinário YF (2017) Caracterização estomática de Epidendrum Lindl. (Orchidaceae, Asparagales) para subsidiar estudos fenotípicos de espécies poliplóides. Universidade Estadual Paulista Júlio de Mesquita Filho, Instituto de Biociências (Campus de Rio Claro).

Arenas W, Cardozo C, Baena M (2015) Análisis de los sistemas de semillas en países de América Latina. Acta Agronómica. 64(3): 239-245.

Bae KH, Ko MS, Lee MH, Kim NY, Song JM, Song G (2013) Effects of $\mathrm{NaOCl}$ treatment on in vitro germination of seeds of a rare endemic plant, Oreorchis coreana Finet. J Plant Biotechnol. 40: 43-48.

Bae KH, Kyoung HO, Soo-Young K (2014) Sodium hypochlorite treatment and light-emitting diode (LED) irradiation effect on in vitro germination of Oreorchis patens (Lindl.) Lindl. Journal of Plant Biotechnology. 41: 44-49.

Barsberg S, Rasmussen HN, Kodahl N (2013) Composition of Cypripedium calceolus (Orchidaceae) seeds analyzed by attenuated total reflectance IR spectroscopy: in search of understanding longevity in the ground. Am J Bot. 100: 20662073.

Baque MA, Shin YK, Elshmari T, Lee EJ, Paek K (2011) Effect of light quality, sucrose and coconut water concentration on the microporpagation of Calanthe hybrids ('Bukduseong' $x$ 'Hyesung' and 'Chunkwang' $\times$ 'Hyesung'). Aust J Crop Sci. 5: 1247-1254.

Betancur J, Pedraza P, González MF, Jaimes M, Giraldo G, Arévalo R (2015) Un parque lleno de orquídeas, Serie Miniguías de Campo del Instituto de Ciencias Naturales No. 24. Instituto de Ciencias Naturales, Universidad Nacional de Colombia, Bogotá y The New York Botanical Garden, New York.

Billard CE, Dalzotto CA, Lallana VH, (2014). Desinfección y siembra asimbiótica de semillas de dos especies y una variedad de orquídeas del género oncidium. Polibotánica. 38: 145-157.

Campacci TVS, Castanho CT, Oliveira RLF, Suzuki RM, Catharino ELM, Koehler S (2017) Effects of pollen origin on apomixis in Zygopetalum mackayi orchids. Flora. 226: 96-103.

Carvalho T, Krzyzanowski F, Castro O, Panobianco M (2013) Tetrazolium test adjustment for wheat seeds. J Seed Sci. 35(3): 361-367.

Carvalho IL, Meneghello GE, Madruga LT, Costa CJ, Nogueira VS (2017) Methodological adjustments to the tetrazolium test in rice seeds. J Seed Sci. 39: 41-49.

Custódio CC, Marks TR, Pritchard HW, Hosomi ST, MachadoNeto NB (2016) Improved tetrazolium viability testing in orchid seeds with a thick carapace (Dactylorhiza fuchsii) or dark seed coat (Vanda curvifolia). Seed Sci Technol. 44: 177188.

Dalzotto CA, García LF, Lallana VH (2013) Efecto del pretratamiento con hipoclorito de sodio en la prueba de viabilidad de semillas de Oncidium bifolium Sims. I Congreso Brasilero de Producción de Orquídeas, Fortaleza, Brasil. 05 al 10 de marzo de 2013. Resumen Expandido. pp. 42-44.

Dalzotto CA, Lallana VH (2015) Efecto de la testa en la germinación in vitro de Bipinnula pennicillata (Rchb. F.) Sisternas \& Salazar (Orchidaceae). Investigación Agraria. 17(2): 116-121.

Deepti S, Gayatri M, Sitikantha S (2013) In vitro seed germination as an aid to conserve Aerides maculosum Lindl. an endemic and endangered orchid of Western Ghats, India. Int J Pharma Bio Sci. 4(B): 478-486.

Deepti S, Gayatri MC, Sitikantha S (2015) In vitro seed germination and plant regeneration of an epiphytic orchid Aerides ringens (Lindl.) Fischer. Ind J Biotechno. 14: 574-580.

Deminicis BB, Vieira HD, Araújo SA, Jardim JG, Pádua F, Chambela-Neto A (2009) Dispersão natural de sementes: importância, classificação e sua dinâmica nas pastagens tropicais. Archivos de Zootecnia. 58: 35-58.

Dowling N, Jusaitis M (2012) Asymbiotic in vitro germination and seed quality assessment of Australian terrestrial orchids. Aust J Bot. 60(7): 592-601.

Doria J (2010) Generalidades sobre las Semillas: Su Producción, Conservación y Almacenamiento. Cultivos Tropicales. 31(1): 74-85.

Fu YY, Jiang N, Wu KL, Zhang JX, Teixeira da Silva JA, Duan J, Liu HT, Zeng SJ (2016) Stimulatory effects of sodium hypochlorite and ultrasonic treatments on tetrazolium staining and seed germination in vitro of Paphiopedilum SCBG Red Jewel. Seed Sci Technol. 44: 77-90.

Gnasekaran PP, Ranjetta M, Maziah S, Razip SS (2012) Effects of complex organic additives on improving the growth of PLBs of Vanda Kasem's Delight. Aust J Crop Sci. 6: 1245-1248.

González J, Lopez-Gallego C, Benavides AM (2017) Abundancia de tres especies de orquídeas con relación a la humedad ambiental y a la humedad del hospedero en un bosque andino. Orquideologia. 34: 65-79.

Hosomi ST, de Souza TB, Custódio CC, Neto NBM (2017) Refining the tetrazolium test for evaluation of Cattleya Iabiata and C. Tigrina seeds viability. Aust J Crop Sci. 11(10): 1320-1326.

Lu Y, Chen YZ, Luo YB, Delph LF (2009) Parthenogenesis maintains male sterility in a gynodioecious orchid. The American Naturalist. 174(4): 578-584.

Instituto de Hidrología, Meteorología y Estudios AmbientalesIDEAM (2018) Grupo de Climatología y Agrometeorología Subdirección de Meteorología-Cartográfia Básica IGAC, Atlas Climatológico de Colombia, Bogotá, Colombia. http://www.ideam.gov.co/

Johansen B, Rasmussen H (1992) Conservaciones ex situ de orquídeas. Opera Botanica. 113: 43-48.

Jeyanthi JAJ, Keng CL, Poobathy R, Subramaniam, S (2011) Selected potential encapsulation dehydration parameters on Dendrobium Bobby Mesina protocorm-like bodies using TTC analysis. Aust J Crop Sci. 5: 1817-1822.

Jeyanthi JAJ, Burkhan J, Sinniah UR, Poobathy R, Subramaniam $S$ (2013) Effect of PVS2 vitrification on Brassidium shooting 
star orchid using protocorm-like bodies (PLBs). Aust J Crop Sci. 7: 1078-1084

Lallana VH, Billard CE, Klug LM (2010) Germinación y desarrollo de plántulas in vitro de Oncidium bifolium Sims var. Bifolium (Orchidaceae). V Congreso Argentino de Floricultura y Plantas Ornamentales. Paraná, Universidad Nacional de Entre Ríos. Libro de Resúmenes. pp. 272-274.

Lallana VH, Di Persia JF (2018) Caracterización morfométrica de semillas de cuatro especies de orquídeas terrestres nativas de Argentina. Ciencia, Docencia y Tecnología. 29(57): 272284.

Lima CB, Boaventura AC, Villela TT (2018) Comparing procedures for performing tetrazolium test on carrot seeds. Horticultura Brasileira. 36(2): 240-245.

Masullo LS, Pina-Rodrigues FCM, Figliolia MB, Americo C (2017) Optimization of tetrazolium tests to assess the quality of Platymiscium floribundum, Lonchocarpus muehlbergianus and Acacia polyphylla DC. Seeds. J Seed Sci. 39(2): 189-197.

Mahmood M, Bee O, Mahmud T, Subramaniam S (2011) The growth and biochemical responses on in vitro cultures of Oncidium taka orchid to electromagnetic field. Aust J Crop Sci. 5: 1577-1587.

Menchaca RA (2011) Manual para la propagación de orquídeas CONACYT-CONAFOR, 1edi, 56, México. http://www.conafor.gob.mx/biblioteca/documentos/

Ministry of Environment and Sustainable Development and the National University of Colombia (2015) Plan para el estudio y la conservación de las orquídeas en Colombia. Textos: Betancur, J., Sarmiento, H., Toro-González, L., Valencia, J., Ministerio de Ambiente y Desarrollo Sostenible, Colombia; Universidad Nacional de Colombia, Bogotá D.C. 336.

Murashige T, Skoog $F$ (1962) A revised medium for rapid growth and bio assays with tobacco tissue cultures. Physiologia Plantarum. 15: 473-497.

Nambiar N, Chong Siang T, Mahmood M (2012) Effect of 6Benzylaminopurine on flowering of a Dendrobium orchid. Aust J Crop Sci. 6: 225-231.

Ordoñez SL, Pillacela DP, Salazar JM, Peña DF (2016) Especificidad del hongo micorrizico (Rhizoctonia sp.) En Phalaenopsis sp., Cymbidium sp., Trichoceros antenifer, Oncidium excavatum, y Cyrtochilum sp. Maskana. 7(1): 8387.

Prenzier S, Morais C, Cito A, Bertoncelli J, Sorace M, Tadeu F (2018) Cryopreservation of Brazilian orchid (Catasetum atratum Lindl.) seed at risk of extinction. Aust J Crop Sci. 12(7): 1051-1057.

Roberts DL, Dixon KW (2008) Orchids. Current Biology. 18: 325329.

Salazar-Mercado S (2012) Germinación asimbiótica de semillas y desarrollo in vitro de plántulas de Cattleya mendelii Dombrain (Orchidaceae). Acta Agronómica. 61(1): 69-78.

Salazar S, Amaya AZ, Barrientos F (2013) Evaluación de diferentes medios de cultivo in vitro en el desarrollo de híbridos de Phalaenopsis (Orchidaceae). Revista Colombiana de Biotecnología. 15(2): 97-105.

Salazar S, Gélvez JD (2015) Determining the Viability of Orchid seeds using the Tetrazolio and Carmín Índigo Tests. Revista de Ciencias. 19: 59-69.

Salazar SA, Vega-Contreras NA (2017) Asymbiotic seed germination and in vitro propagation of Cattleya trianae
Linden \& Reichb.f. (Orchidaceae). Acta Agronómica. 66(4): 544-548.

Salazar S, Botello E (2018) Viabilidad de semillas de Glycine max (I.) Utilizando la prueba de tetrazolio. Revista de Investigación Agraria y Ambiental. 9(2): 89-98.

Salazar S, Maldonado H, Quintero J (2018) Evaluación de la calidad fisiológica de las semillas de Linum usitatissimum $\mathrm{L}$. con la prueba de tetrazolio. Avances en Investigación Agropecuaria. 22 (3): 46-56.

Salazar S, Torres C, Rojas J (2019) Cytotoxic evaluation of sodium hypochlorite, using Pisum sativum $\mathrm{L}$ as effective bioindicator. Ecotoxicology and Environmental Safety. 173: 71-76.

Salazar SA, Quintero JD, Moreno LY (2020) Improvement of the methodology of the tetrazolium test using different pretreatments in seeds of the genus Epidendrum (Orchidaceae). Journal of Seed Science. 42: e202042013.

Santos L, Marquez F, Balisterio MF, Américo C (2017) Optimization of tetrazolium tests to assess the quality of Platymiscium floribundum, Lonchocarpus muehlbergianus and Acacia polyphylla DC. Seeds. J Seed Sci. 39: 189-197.

Silva PS, Damásio da Costa O, Azevedo dos Santos L, Pessoa FL, Pereira da Costa N (2015) Contagem de sementes de cápsulas de Spathoglottis plicata Blume e Polystachya estrellensis Rchb. F. II SIMBRAORQ. Joboticabal, SP. Brasil. UNESP/FAC, Livro resumos. pp. 22-25.

Sulong NA, Khalil NIM, Dahari MI, Zakaria AA (2016) Effect of Different Sound Genres on In Vitro Seed Germination of Grammatophyllum Hybrid and Grammatophyllum Stapeliiflorum Orchids. The Open Conference Proceedings Journal. 7: 94-103.

Strobel T, Koch F, Geison RA, Szareski V, Carvalho I, Nardino M, Souza V, Tiago Z, Queiroz Z, Amaral F, Aumonde TZ (2016) Physical and physiological quality of soybean seeds harvested under different trial systems after storage periods. Aust J Basic Applied Sci. 10: 124-130.

Tukey JW (1994) The problem of multiple comparisons. En: H. L. Braun (ed.). The collected works of John W. Tukey. Nueva York: Chapman and Hall 8(1): 1-300.

Van der Niet T (2018) Autonomous self-pollination in the South African orchid Satyrium rupestre Schltr. South Afr J Bot. 117: 215-221.

Vij S, Pathak P (2012) Orchid Diversity: Conservation and Utilization. Proceedings of the National Academy of Sciences. India Section B. Biological Sciences. 82(2): 295300.

Vudala SM, Padial AA, Ribas LLF (2019) Micropropagation of Hadrolaelia grandis through transverse and longitudinal thin cell layer culture. South Afr J Bot. 121: 76-82.

Waraich EA, Ahmed Z, Ahmad R, Yasin Ashraf M, Saifullah N, Naeem S, Rengel Z (2013) Camelina sativa, a climate proof crop, has high nutritive value and multiple-uses: $A$ review. Aust J Crop Sci. 7(10): 1551-1559.

Zhang S, Yang Y, Li J, Qin J, Zhang W, Huang W, Hu H (2018) Physiological diversity of orchids. Plant Diversity. 40(4): 196208.

Zucareli C, Malavasi MM, Fogaça CA, Malavasi UC (2001) Preparo e coloração de sementes de farinha-seca (Albizzia hasslerii (Chodat) Burr) para o teste de tetrazólio. Revista Brasileira de Sementes. 23(2): 186-191. 